\title{
Cost of best management practices to combat agricultural runoff and comparison with the local populations' willingness to pay: Case of the Austreberthe watershed (Normandy, France)
}

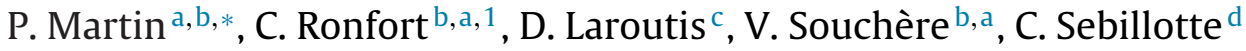 \\ a AgroParisTech, UMR 1048 SAD-APT, F-78850 Thiverval-Grignon, France \\ ${ }^{\mathrm{b}}$ INRA, UMR 1048 SAD-APT, F-78850 Thiverval-Grignon, France \\ ' Unité Agriterr - Lecor ESITPA, 3, rue du Tronquet, CS 40118, F-76134 Mont-Saint-Aignan Cedex, France \\ d INRA, UR 1303 ALISS, F-94205 Ivry-sur-Seine, France
}

\section{A R T I C L E I N F O}

\section{Article history:}

Received 26 August 2013

Received in revised form

17 November 2013

Accepted 21 December 2013

\section{Keywords:}

Runoff risk

Scenario

Dairy farm

Willingness to pay

LUCC

LPIS

\begin{abstract}
A B S T R A C T
Land Use and Cover Changes (LUCCs) significantly increase the frequency of mudflows in the silty areas of north-western Europe and particularly in the NUTS 3 Seine-Maritime region (France). Predicting the effects of a range of possible LUCCs helps local authorities choose policies that can help to mitigate the risks to which local populations are exposed. In this article we build scenarios for changes in farming systems, with a 2015 horizon and with 2007 as the initial situation. These scenarios are assessed through combined biophysical and economic approaches. Two scenarios for the disappearance of dairy farming are chosen. One scenario has no public-action program (StopMilk), while the other one has a program based on the funding of best management practices (StopMilk-E). These scenarios are assessed at the small watershed scale $\left(7 \mathrm{~km}^{2}\right)$ in terms of both changes in farming systems and effects on runoff (use of the STREAM model). Finally, the economic evaluation of additional costs of StopMilk-E is extrapolated at the level of the Austreberthe watershed syndicate $\left(214 \mathrm{~km}^{2}\right)$, using the French Land Parcel Identification System (LPIS) with a spatially referenced database of cropping plans. StopMilk leads to a significant increase in runoff whereas the local public-action program proposed under StopMilk-E reduces runoff to below the 2007 level. The Austreberthe watershed residents' willingness to pay for a 15-year program is around $€ 395,000 /$ year, which is not sufficient to balance the cost of the modified farming practices ( $€ 640,000 /$ year over the first 3 years). Funding of the practices would require either subsidies from a higher level (Europe), borrowing by the community, and/or a more selective approach in the type and the location of farming practices to be funded. The method used for calculating costs at the watershed syndicate level shows the huge potential of new databases like LPIS (available in France since 2006) for the assessment of environmental issues.
\end{abstract}

(C) 2013 Elsevier Ltd. All rights reserved.

\section{Introduction}

Recurring mudflows in the silty areas of north-western Europe constitute a substantial economic burden for local communities (Boardman et al., 1994, 2006; Evrard et al., 2007). These mudflows are the result of erosion occurring on agricultural land located upstream of urban areas. The extent of the damage depends on the spatial and temporal organization of cropping systems upstream

\footnotetext{
* Corresponding author at: UMR SAD-APT, bât EGER, BP01, 78850 ThivervalGrignon, France. Tel.: +331308159 30; fax: +33130815939.

E-mail addresses: pmartin@agroparistech.fr, philippe.martin@agroparistech.fr (P. Martin), couesnonaval@cc-pontorsonmtstmichel.org (C. Ronfort).

1 Current address: Syndicat de Bassin Versant Basse vallée et Moyen Couesnon, Parc d'activité de Pontorson - Mont Saint Michel, 50170 Pontorson, France.

Tel.: +332338915 11; fax: +33233605283.
}

(Joannon et al., 2006) and land use downstream (Heitz et al., 2009). For three decades, the local authorities have tried to prevent mudflows by setting up devices such as retention ponds (Verstraeten and Poesen, 1999) to hold back earth-laden waters flowing off agricultural lands. At the same time, policies have been followed usually voluntarily - to develop some infrastructures to limit water concentration (e.g. hedges) or soil erosion in thalwegs (e.g. grassed waterways). The aim is also to modify the agricultural practices of the farmers concerned (Boardman et al., 2003a; Fullen et al., 2006), with a view to limiting the quantity of earth-laden water running off farmland. In this paper we will focus on local policies with regard to changes in farming practices.

Farmers' practices are based on both the internal logic of their farming system and on an adaptive response to external signals (Leenhardt et al., 2010). Some external signals such as soil and climate may be considered as constant in time (on a rather short 
time-scale). Many other external signals are more variable in time: existence of sales channels, price levels, technical innovations, and national regulatory constraints. For European farmers the Common Agricultural Policy (CAP) is a major external signal (Boardman et al., 2003b). Changes in the CAP and international regulations can have significant consequences on land use and cover (Rounsevell et al., 2003; Therond et al., 2009; Valbuena et al., 2010), with induced consequences on the variation in the runoff risk for local populations. Retrospective analyses have shown how prior changes in the CAP have led to local increases in mudflow risks (Souchère et al., 2003; Evrard et al., 2007). The future of the post-2013 CAP is still under discussion in mid-2013. For local communities subject to mudflow risks, it is important to know whether an adaptation of their local policies would be able to mitigate possible side effects of changes in agricultural external signals.

A scenario methodology can be used to test this adaptive ability (Godet, 2000). For a given region, a range of potential changes can be combined to define scenarios of changes in cropping systems (Ewert et al., 2009), which can then be used to test the impact of certain local policies. The tested impacts are likely to be both environmental (using biophysical models (Therond et al., 2009)) and economic (policy cost), at least.

For European countries, the economic performance of policies applied to a range of farms can be evaluated using accounting databases like the FADN (Farm Accountancy Data Network). The FADN provides extensive data on the characteristics of individual farms throughout the EU. Accounting data are generally used for the NUTS2 level (NUTS = Nomenclature of Territorial Units for Statistics) (Reidsma et al., 2009). For instance, in France, NUTS2 regions correspond to "région" (e.g. Haute-Normandie), and NUTS3 to "département" (e.g. Seine-Maritime). Econometric optimization techniques have been developed to determine new combinations of practices and their associated cost under a constraint function (Jacquet et al., 2011). These techniques are adapted to areas above the regional level (NUTS0 to NUTS2). For lower levels corresponding to the local communities (Local Administrative Unit or LAU) that we are working on, FADN databases can be inconsistent with local farm diversity (Jacquet et al., 2011). At the LAU level we also have a problem of border effects: local policies can develop incentives for farmers but these incentives are limited to the parcels located within their jurisdiction, as the local authorities see no advantage in subsidizing their neighbors' parcels. Individual farm areas in Western Europe are often large and scattered across different LAU, whereas information in an accounting database is not spatial. The "border effect" can be neglected when accounting data are used at the regional level, but not at the local level. Assessment of the local policy effects should use spatial databases, including the boundaries of farm areas. This type of database has been generalized in Europe in the framework of the CAP regulations. Article 20 of the European Regulation (EC) No. 1782/2003 stipulates the use of a Land Parcel Identification System (LPIS) established on the basis of maps, land registry documents, or other documents (Inan et al., 2010). For France, this type of data has been available since 2007 in the RPG (Registre Parcellaire Graphique) database. This database includes the delimitation of each farm area (scale of 1:5000) with its production blocks (e.g. fields of the same farm with common borders), and both the list of crops and corresponding areas cultivated in each production block. This type of data has been used in various countries - France (Fuzeau et al., 2012), Austria (Schönhart et al., 2010), and Belgium (Leteinturier et al., 2006) - but as far as we know, no paper has taken the farm level for scenario building. As no accounting data are given with LPIS information, the cost of agricultural practices needs to be found elsewhere, using interviews with farmers on their expert knowledge, or literature reviews.

The cost of local policies is generally financed by local taxes. This raises the question of local populations' willingness to pay
(WTP) (Hanemann, 1994) for this type of program. The contingent valuation method (CVM) can monetarily quantify the values that individuals assign to an environmental good. This method has emerged as one of the few that includes values of both use and nonuse, including the value of existence (Quiggin, 1998a,b). There has recently been a number of CVM-based economic studies on the risk of flooding. Zhai and Ikeda (2006), for example, discuss the acceptability of flood risks and the economic cost of evacuation in case of a disaster in Japan. Brouwer et al. (2009) examine the economic evaluation of exposure to flood risks in developing regions such as Bangladesh. In a survey of over 1000 households in the Shonai-Toki river basin in Japan, Zhai (2006) studied residents' WTP for flood risk reduction.

Our paper deals with the side effects on mudflow risks of potential changes in major determinants of agricultural practices in Europe (e.g. CAP), at the local level. In considering a predefined scenario of changes by 2015 and a first environmental assessment of this scenario (Ronfort et al., 2011), we have two objectives. First, we want to quantify the costs for local communities wishing to create incentives to change agricultural practices in order to counter the initial scenario. To this end we have tested the use of LPIS data in combination with findings from farmers' interviews and a literature review. The second objective is to estimate the local populations' willingness to pay for such an incentive program (using the CVM method) and to compare it with the estimated cost of the program.

\section{Materials and methods}

\section{The study zone}

The work was conducted in the French NUTS3 Region, Seine-Maritime, which is part of a NUTS2 region, Normandy. Seine-Maritime is representative of the European Loess Belt agricultural regions concerned by mudflows (Boardman et al., 1994; Verstraeten and Poesen, 1999). Natural conditions (e.g. deep fertile silty soils and regular rainfalls ranging from 650 to $1000 \mathrm{~mm} / \mathrm{year}$ ) and local agro-industrial networks are suited to a huge range of industrial crops and livestock production. The regional capital (Rouen) is the top-ranking grain port in Europe, and livestock farming, mostly with cattle, occupies $31 \%$ of the regional usable agricultural area (figures for 2010 from the national agricultural census). But Seine-Maritime is also characterized by a regular decrease of grassland areas due to encroaching urbanized areas and croplands, which leads to an increase in runoff risk (Souchère et al., 2003). In 2000, after several years of mudflow crisis, the 745 municipalities of Seine-Maritime organized themselves into 20 watershed syndicates in charge of protecting people and properties from mudflows (Fullen et al., 2006; Martin et al., 2010). We chose to work at the level of one of those syndicates called Austreberthe. The Austreberthe watershed extends over all or part of 37 municipalities inhabited by around 37,000 residents in an area of $214 \mathrm{~km}^{2}$ in Seine-Maritime. At the beginning of the research program the two objectives presented in this paper (cost quantification and WTP assessment) were separate. Despite the fact that the WTP assessment was carried out for another watershed called Commerce (Fig. 1), we decided to compare the WTP data of Commerce with the cost evaluation carried out for Austreberthe because these two watersheds have many common features. They are geographically close to each other, are both tributary river basins of the Seine with high population density, located mainly in the valleys, and have high mudflow risk exposure. The Austreberthe watershed experienced an average of 27 days of flooding between 1983 and 2000, against 24 days for the Commerce Valley. Since 1983 , as referenced in the national natural disaster database, every 

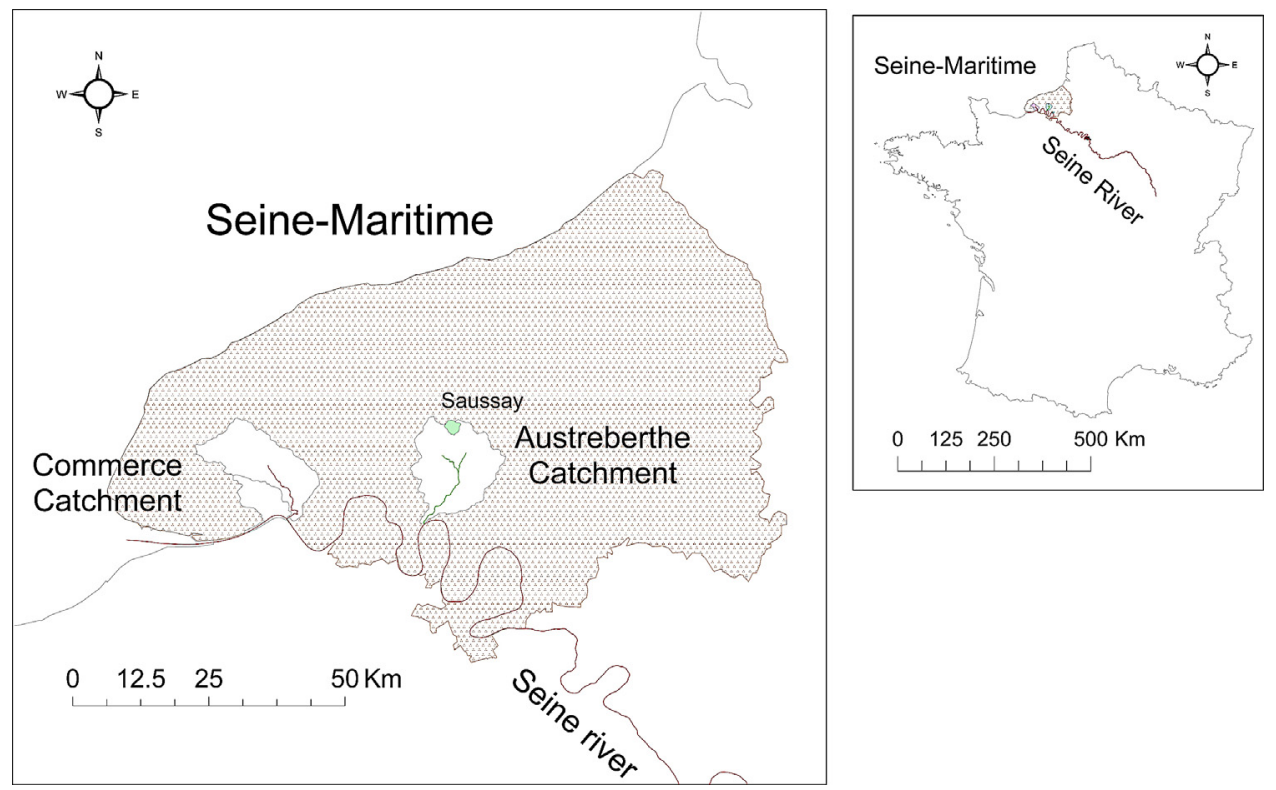

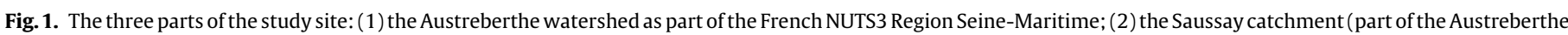

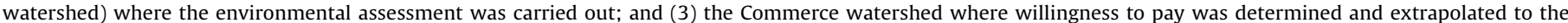
Austreberthe watershed.

municipality in these two watersheds has declared a mudflow at least once. Table 1 shows other similarities in terms of both human features (structure of the socio-professional population, population distribution between rural and urban areas, average household size) and physical aspects (types of soil, range of slopes, land use). The global physical organization is also the same. The deep silty soils are located upstream of the watershed on the lower slopes where annual rainfalls are heavier. Mean farm areas are also not statistically different between the two watersheds ( 79 ha for Austreberthe and 88 ha for Commerce, $T$ Student test probability $=0.5$ ).

For Austreberthe, the environmental assessment of the scenarios was carried out on the scale of the Saussay agricultural catchment $\left(49^{\circ} 38^{\prime} 01.82^{\prime \prime} \mathrm{N}, 0^{\circ} 56^{\prime} 19.58^{\prime \prime}\right.$ E) in the northern upstream part of Austreberthe (deep silty soils). The Saussay catchment was chosen for its diversity of production systems (mixed farming, cereal crops, etc.), making it sensitive to a wide range of

Table 1

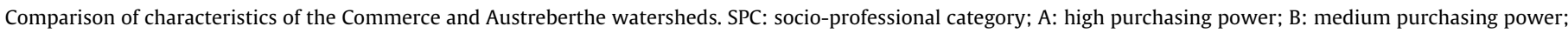
C: low purchasing power.

\begin{tabular}{|c|c|c|c|}
\hline & & Commerce & Austreberthe \\
\hline \multirow[t]{8}{*}{ Population } & SPC A & $11.36 \%$ & $11.9 \%$ \\
\hline & SPC B & $43.69 \%$ & $41 \%$ \\
\hline & SPC C & $33.98 \%$ & $27.8 \%$ \\
\hline & Average household size & 2.63 & 2.57 \\
\hline & Rural population/urban pop. & $45 / 55$ & $45 / 55$ \\
\hline & Population (male) & $49.4 \%$ & $49.1 \%$ \\
\hline & Population (female) & $50.6 \%$ & $50.9 \%$ \\
\hline & Population density & 140 per $\mathrm{km}^{2}$ & 160 per $\mathrm{km}^{2}$ \\
\hline \multirow[t]{3}{*}{ Soil (\% of area) } & Thin layer of chalky soil & 6 & 2 \\
\hline & Disturbed silty soil on flint clay & 27 & 34 \\
\hline & Deep silty loamy soil & 67 & 64 \\
\hline \multirow[t]{4}{*}{ Slopes (\% of area) } & $0-2 \%$ & 65 & 56 \\
\hline & $2-5 \%$ & 22 & 23 \\
\hline & $5-10 \%$ & 9 & 14 \\
\hline & $>10 \%$ & 4 & 7 \\
\hline \multirow[t]{4}{*}{ Annual rainfall in $\mathrm{mm}$ (\% of area) } & $650-750$ & 13 & 3 \\
\hline & $750-850$ & 29 & 38 \\
\hline & $850-950$ & 26 & 59 \\
\hline & $>950$ & 32 & 0 \\
\hline \multirow[t]{6}{*}{ Land use } & Urban & 9 & 6 \\
\hline & Industrial & 2 & 1 \\
\hline & Arable land & 56 & 61 \\
\hline & Grassland & 17 & 18 \\
\hline & Forest & 13 & 11 \\
\hline & Other uses & 3 & 3 \\
\hline \multirow[t]{3}{*}{ Farms } & Mean area (ha/farm) & 88 & 79 \\
\hline & Medium area (ha/farm) & 77 & 68 \\
\hline & Number & 436 & 383 \\
\hline
\end{tabular}


scenarios. This catchment covers an area of $7 \mathrm{~km}^{2}$ and is drained by several dry thalwegs that join upstream of the outlet. Farmland accounts for $87 \%$ of the catchment area and is farmed by 23 farmers: 5 of them have cereal farms (CF), 13 have mixed dairy farms (DF) and 5 have mixed suckler farms (SF).

\section{Presentation of the scenarios for 2015 and their environmental} assessment

In this part we will briefly run through the main features of both the initial scenario and its environmental assessment as they are presented in detail in Ronfort et al. (2011). We also present the scenario variation that we used for this paper.

The scenarios were constructed using the SYSPAHMM foresight method (Sebillotte and Sebillotte, 2010; Ronfort et al., 2011). The subject under consideration was the evolution of cropping systems. The baseline was 2007, e.g. the year of the collaborative work we carried out with local stakeholders and experts to build the scenarios. The target year was 2015, as many changes in the CAP were expected to have been decided by then (revision of farm subsidy rules and sugar beet quota systems; end of milk quotas). As presented in the introduction, these potential changes may have crucial impacts on soil erosion risks. We kept the same initial scenario that Ronfort et al. (2011) had worked on, called "Territory loses its traditional production in favor of cash crops in a context of rural exodus", but shortened its name to "StopMilk". In this scenario, the territory loses its traditional milk production in favor of cash crops as a result of inter-regional competition. Cash crops are less diverse than in 2007 due to the disappearance of sugar beet and protein peas, and to the reduction of the area under flax cultivation. The reduction in crop diversity is the result of international competition in the context of very low customs barriers. The reduction in both industrial crop and grassland areas is compensated by an increase in cereals crops, mainly wheat, barley and oil seed rape. This happens in a context of rural exodus and the local authorities' lack of interest in environmental quality, evidenced in the small number of regulatory constraints. StopMilk was chosen as an initial scenario for 2015 because the researchers responsible for developing scenarios felt that it corresponded to one of the worst possible situations for limiting erosive runoff due to the loss of grasslands caused by cessation of dairy farming (Souchère et al., 2003). To test the capacity of local communities to limit runoff using incentives for specific agricultural practices, we introduced a variation of StopMilk that we called StopMilkE (E for environment). The StopMilk-E scenario differs from StopMilk in that it envisages stricter environmental regulations for farmers at the local level. According to French regulations, which are not considered to have changed by 2015, the additional constraints imposed on farmers in StopMilk-E require compensation to be paid to farmers for increased costs, at least initially. As Stop-Milk is one of the worst scenarios, working on the StopMilk-E scenario is a means to evaluate the upper cost of a program set up by local communities to limit agricultural runoff. Note that the global cost of the program can be reduced by $50 \%$ by using European subsidies from the so-called "second pillar" of the European Common Agricultural Policy (European Agricultural Fund for Rural Development).

The environmental assessment of the scenario, carried out on the scale of the Saussay watershed, is based on the use of a runoff model fed by input data on both crop allocation to each field and farmers' practices for the different crops (Ronfort et al., 2011). Note that the type of farming systems and corresponding crop acreages and crop allocation to fields are exactly the same for StopMilk and StopMilk-E. The only difference between the two scenarios is a generalized use of best management practices for runoff mitigation in StopMilk-E. Table 2 presents these best management practices grouped together according to the targeted period of protection (winter or spring) and the crops concerned. For StopMilk, agricultural practices are those of 2007. Among the best management practices, catch crops were the only ones really used in 2007 and only for a few hectares. Crop acreage for each farm for 2015 is obtained using the qualitative information about crop substitution contained in the scenario narrative. This qualitative information was combined with rules for crop rotations, elicited during farmer surveys in 2007 on farming practices, and processed using the LandsFacts computer model (Castellazzi et al., 2010; Ronfort et al., 2011). The LandsFacts model allowed us to generate a series of spatial allocations of crops to fields on each farm considered.

The impact of the scenario on the erosive runoff was assessed using the STREAM model developed in this region (Cerdan et al., 2002) and used in many research studies in Seine-Maritime over the last 10 years (Evrard et al., 2010). STREAM is a spatial model for agricultural watersheds and runs under $\operatorname{ArcGIS}^{\circledR}$. Starting from a rainfall event, the watershed topography, the field pattern and their surface states, STREAM generates a runoff-concentration network and calculates the runoff throughout this network up to the outlet. We worked on the two periods at risk of runoff in this region: December and May. For each of these two months, we used one thunderstorm rainfall event of $22.0 \mathrm{~mm}$ (return period between 5 and 10 years). Results for StopMilk-E are compared to those obtained for 2007 and StopMilk. Starting from the same crop areas, we can have different crop allocations for each field of each farm. These allocations can be determined with the LandsFacts model. When integrated at the watershed level these variations in crop allocations can generate variation in runoff volume at the outlet of the watershed (Joannon et al., 2006). To deal with this problem we decided to generate 50 different crop allocations for each situation (i.e. 2007, StopMilk and StopMilk-E) using LandsFacts. The environmental evaluation of each situation was the mean value of the

\section{Table 2}

Cropping techniques, desired period of protection against runoff, targeted crops, and cost/ha.

\begin{tabular}{|c|c|c|c|}
\hline & Technique & Targeted crops & Total cost/ha \\
\hline Winter protection & Catch crop & Before any spring crop & $€ 75^{\mathrm{a}}$ \\
\hline \multirow[t]{4}{*}{ Spring protection } & Micro-dam & Potatoes & $€ 10^{\mathrm{b}}$ \\
\hline & Rotary hoeing & Wheat and winter barley & $€ 43^{c}$ \\
\hline & Hoeing & Forage and sugar beet, maize & $€ 35^{\mathrm{d}}$ \\
\hline & In-field grass buffer strip & For all spring crops & $€ 280^{\mathrm{e}}$ \\
\hline
\end{tabular}

Notes: The cost of farming practices refers to additional costs over and above the cost of current practices.

a http://www.europedirectplr.fr/programmes/orientations-nationales-pour-le-feader-27.html; http://www.europedirectplr.fr/upload/file/PDRH_FEADER_2007_2013_ tome4.pdf.

b http://www.areas.asso.fr/images/formations/resultats_Gembloux_JP_Barthelemy.pdf.

Purchase cost of $€ 4000$ amortized over 10 years at the rate of 20 ha per year.

c http://www.rdtrisques.org/projets/digetcob/bib/rapports_et_travaux_diget_cob/houe_rotative_1.pdf/download.

d http://www.rdtrisques.org/projets/digetcob/bib/rapports_et_travaux_diget_cob/les_bineuses_1.pdf/download.

e http://www.europedirectplr.fr/upload/file/PDRH_FEADER_2007_2013_tome4.pdf.

All links have been tested and are working as at 17 November 2013. 
runoff simulated at the outlet of the watershed with the STREAM model for these 50 crop allocations. Note that it was not possible to carry out the environmental assessment of the scenario at the scale of the Austreberthe watershed as a whole because not all the information required for the use of STREAM was available at this scale (e.g. tillage direction, local slope with high precision, etc.).

\section{Economic evaluation of the StopMilk-E scenario}

The economic evaluation consists in calculating the global cost that local communities would have to pay to farmers to balance the additional costs associated with the implementation of the best management practices (BMP) for StopMilk-E. Each BMP is associated with specific types of crops (Table 2). The first step of economic evaluation is therefore a calculation of the area under each crop type in the Austreberthe watershed under the 2015 StopMilk-E scenario. This necessitates the identification of the type of each of the 383 farms of the Austreberthe watershed in 2007. We then had to apply rules of land use change according to both the disappearance of dairy farms and crop diversity reduction. In Ronfort et al. (2011), the crop areas at the level of the Saussay catchment were calculated using direct survey data fed into the LandsFacts model. This was not possible for the larger scale of Austreberthe. To overcome this difficulty we used the French Land Parcel Information System called RPG (see Introduction) which anonymously provides the location of each farmer's production blocks, as well as crop types and the areas under cultivation in these production blocks.

From surveys conducted at the Saussay site, we drew up a decision tree to assign a farm to one of the three farm types (suckler farm, cereal farm, dairy farm) solely on the basis of information available in the RPG (Fig. 2). This decision tree was first tested for the Saussay watershed before being used for the whole of Austreberthe. The application of the decision tree to the whole of Austreberthe allowed for the identification of those dairy farms that are expected to cease their activity by 2015 (StopMilk and StopMilk-E). For each of these dairy farms we had to specify the type of farm they would be in 2015 , that is, either a suckler or a cereal farm. The main difference between the two types, regarding runoff production, is the type of barley they grow on their fields, i.e. either spring or winter, with consequences on the period of runoff risk. Cereal farms prefer spring barley for malt production, with better economic returns, whereas suckler farms prefer winter barley, due to its higher yields of both grain and straw for their own animals.

Surveys conducted at the Saussay site showed that the proportion of mandatory permanent grass (PGm) in the total permanent grass area (PG) influenced the evolution of farms that ceased milk production. PGm corresponds to permanent grass that cannot be cultivated, for reasons specific to the farm: mainly steep slope

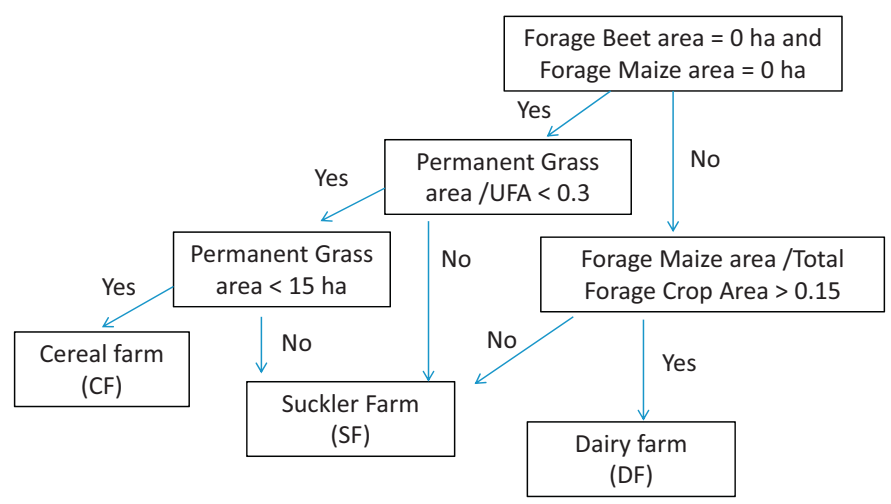

Fig. 2. Decision tree for classifying farms into 3 classes based on the Land Parcel Identification System database for the Saussay site (UFA: usable farm area). and soil type, but also field size, leasing restrictions, etc. High $\mathrm{PGm} / \mathrm{PG}$ ratios lead to a conversion to the suckler farm type. Lower ratio leads to the cereal farm type. The actual mean PGm/PG ratio expressed by dairy farmers was $18 \%$ in Saussay. For the larger scale of Austreberthe we had no information about PGm in the RPG database. The PGm proportion was adjusted to $25 \%$ as the proportion of good soil was lower at the large scale of Austreberthe than in the local conditions of Saussay. Using this ratio we calculated the PGm for each farm and, based on Ronfort et al. (2011), considered that dairy farms which had more than 5 ha of PGm in 2007 (more than 20 ha of PG) moved toward becoming suckler farms in 2015. The others were transformed into cereal farms. Forage crops such as maize and fodder beets disappeared in all cases.

For each farm, areas released from some crops were allocated to other crops. We had 3 components in the released areas (RA). RA1 represented the disappearance of all 2007 areas of peas and sugar beet. RA2 concerned dairy farms whose conversion released areas used in 2007 for growing forage crops (permanent grass, corn silage and fodder beet). RA3 concerned farms that were growing flax in 2007. The RA3 value depended on the relative importance of flax in 2007 for each farm. Flax is a speculative crop that requires technical expertise to farm. When prices rise, non-specialist farmers are attracted to it and opportunistically grow small quantities without taking too much risk. These same farmers then abandon the crop when prices fall (case of the StopMilk-E scenario). Flax is also cultivated by specialist flax farmers who plant it over much of their land. While the minimum crop return period for the same field is 6 years for flax, these farmers can reduce it to 3 years when prices rise. Based on this, we considered a farmer to be a non-specialist when the proportion of flax on his farmlands (FA/TAA where FA is flax area and TAA is total arable area) was equal to or below a value set at $5 \%$ for the Austreberthe watershed in 2007. These areas were fully released in the StopMilk-E scenario. A specialist farmer is one whose area under flax cultivation is greater than $16.6 \%$ of his 2007 farmland area. For this type of farmer, flax areas were fixed for 2015 at $16.6 \%$ in StopMilk-E (1/6th of the area or return period of 6 years). Farms with flax between $5 \%$ and $16.6 \%$ in 2007 kept the same flax areas in StopMilk-E (i.e. R3 $=0$ ha). For each farm identified in the RPG, the total released areas RA=RA1 + RA2 + RA3. Farm areas released from various crops went to the remaining crops, i.e. wheat, barley and rapeseed, while maintaining the ratios between the areas of these 3 crops at 2007 levels. This calculation was made for all farms with at least one field in the Austreberthe watershed, by suitably weighting those crop rotations on the farmlands that were actually within the Austreberthe watershed syndicate, as this syndicate would only subsidize practices implemented in its own territory. The surface areas of the different crops were then divided into winter and spring crops, which are the relevant categories for the implementation of practices to combat runoff (see Table 2).

We evaluated this method on the Saussay site by comparing the results thus obtained with the RPG and those calculated more precisely using the LandsFacts model.The RPG gave essentially the same results as LandsFacts for grasslands but generated a difference of about $5 \%$ for both spring crops and winter crops. Due to this limited difference we decided to apply the RPG method to the entire Austreberthe watershed.

The above methodology gave us the 2015 areas of each crop of the Austreberthe watershed on which it was possible to implement practices referenced in Table 2 for the StopMilk-E scenario. We then conducted a search in the literature in order to estimate the potential costs to society of these practices. We took only the additional costs to the farmers into account. For instance, in the case of potato micro-dams we took into account only the use of the additional tool (which is only for runoff reduction and has no agronomic interest) and not the cost of the use of the tractor, for example, that would in any case have been used by the farmer for potato plantation. 
Conversely, for a technique that requires an additional intervention (compared to farmers' usual practices), the full cost of the technique is taken into account (e.g. planting catch crops). This type of calculation is the one adopted in France and validated by the European Commission for agri-environmental measures. The calculated cost is a maximum cost since all surface areas liable to a change in farming practices have been taken into account.

To sum up, the economic evaluation of the StopMilk-E scenario relies on the value of 3 types of parameter. The first type concerns the farm typology in 2007 (Fig. 2). The second concerns changes in cropping plans between 2007 and 2015 (proportion of mandatory permanent grass in all permanent grass, and proportion of flax in the arable area). The third type is about the additional cost of best management practices to farmers. A sensitive analysis has been carried out on these 3 types of parameter.

\section{Evaluation of willingness to pay}

To assess the local populations' willingness to pay, we applied the contingent valuation method (CVM) to quantify the values that individuals assign to an environmental good at a given point in time. The construction and administration of the questionnaire are central to the CVM method. Thus, in order to describe as accurately as possible the main impacts of floods associated with erosive runoff, the economists undertaking this work joined forces with agricultural scientists specialized in erosion. To test any possible biases, we introduced control questions into the survey for assessing the respondents' comprehension of the global issue, the importance of involvement, the lack of knowledge on the technical subjects, etc. (Mitchell and Carson, 1989). The first draft of the questionnaire was tested on 17 individuals to identify ambiguities or possible misinterpretations of questions, and to judge the clarity of the visual aids such as photographs or maps. The results obtained for Commerce Valley have been extrapolated for the Austreberthe watershed by relying on their almost equal distribution in terms of socio-professional category, sex, and population density.

The final questionnaire consisted of 48 questions and was divided into three parts:

- The first part concerned the respondents' knowledge of the phenomenon of erosive runoff and its possible consequences in Commerce Valley. A set of questions determined whether they were familiar with the concept of erosive runoff, whether they were aware of any specific structures or arrangements to deal with it, etc.

- The second part was designed to determine the individuals' willingness to pay (WTP) for a program to combat erosive runoff, in particular to prevent flooding in Commerce Valley. A description of an anti-flooding program was provided to them and their views on it were elicited (cf. Appendix A). It was clearly explained that the anti-flooding program was a complementary program based on diverse options, including the changes of agricultural practices presented in this paper (cf. Appendix A). Respondents were asked about their possible financial participation (spanning 15 years) through property tax or via the establishment of a special fund. It is indeed necessary for the payment mechanism to be credible (Mitchell and Carson, 1989).

- Finally, the third part collected standard socio-economic data such as the number of persons in the household, their education levels, the overall net household income, etc.

The final questionnaire was administered to adult residents (18 years or older) of Commerce Valley. The sampling method adopted was that of quotas by sex, age and socio-professional category (SPC). A total of 220 individuals were interviewed in person at their homes. Except for the format of the questions, the guidelines recommended by the National Oceanic and Atmospheric Administration Panel (Arrow et al., 1993) were followed to design and administer this questionnaire.

The factors behind the WTP were determined with a censored variable model (Tobit) given the large number (58\%) of individuals who expressed their WTP as equal to 0 Euros.

$W T P_{i}= \begin{cases}x_{i} \beta+u_{i} & \text { if } x_{i} \beta+u_{i}>0 \\ 0 & \text { else }\end{cases}$

where $x_{i}$ corresponds to the explanatory variables (e.g. sex, socioprofessional category, etc.) which can take values of 1 or 0 . $\beta$ is the coefficient of these variables and $u_{i}$ is the random term following a normal distribution with a mean of 0 and a variance of $\sigma^{2}$.

\section{Results}

\section{Environmental assessment of StopMilk-E}

The evolution of the crop acreages for Saussay is shown in Table 3 (after Ronfort et al., 2011). This table gives the proportion of the individual crops of the entire farm territories in 2007 and for 2015 (StopMilk and StopMilk-E scenarios). In coherence with the two scenarios, Table 3 shows a significant decrease in permanent grassland areas, and the complete replacement of some crops (sugar beet, peas) by others (spring barley). On the whole, there is an increase in the area under winter crops compared to spring crops.

Individual farm acreages were used as input data for the LandsFacts model. The outputs of the LandsFacts model were then aggregated to generate 50 different crop allocations at the watershed level (Saussay) as input data for the STREAM model. Results obtained with the STREAM model for Saussay (Fig. 3) show that the StopMilk-E scenario reduced the level of runoff to a level actually lower than both StopMilk and the initial situation of 2007 for both the winter and the spring periods. The reduction of runoff obtained with the StopMilk-E scenario for winter and spring periods is $62 \%$ and $82 \%$ respectively. The low standard error values indicate that, for the Saussay catchment, the different crop allocations to the fields have a low impact on runoff variation. This is probably because for each situation (2007, StopMilk and StopMilk-E) the most important crops for runoff mitigation (e.g. permanent grasslands) remain on the same fields. For each situation the runoff for the winter period is always higher than the runoff for the spring period. This is probably because of a high rate of winter crops

Table 3

Proportions of individual crops of all farm territories in 2007 and for the 2015 scenario for Saussay; UFA: usable farm area (after Ronfort et al., 2011).

\begin{tabular}{llcc}
\hline & & $\begin{array}{c}\text { Initial situation } \\
(2007) \% \text { of UFA }\end{array}$ & $\begin{array}{l}\text { Scenario } \\
(2015) \% \text { of UFA }\end{array}$ \\
\hline \multirow{2}{*}{ Winter crops } & Winter wheat & 33.8 & 39.6 \\
& Winter barley & 6.5 & 7.7 \\
& Oilseed rape & 9.8 & 25.3 \\
& Total winter crops & 50.1 & 72.6 \\
\multirow{5}{*}{ Spring crops } & Fodder beet & 0.9 & 0.2 \\
& Sugar beet & 1.6 & 0.0 \\
& Flax & 5.3 & 3.7 \\
& Pea & 1.4 & 0.0 \\
& Spring barley & 0.0 & 0.6 \\
& Maize & 8.7 & 5.9 \\
& Potatoes & 7.4 & 17.2 \\
& Total spring crops & 25.3 & 10.2 \\
\hline \multirow{2}{*}{ Grasslands } & All types & 24.6 & \\
\hline
\end{tabular}



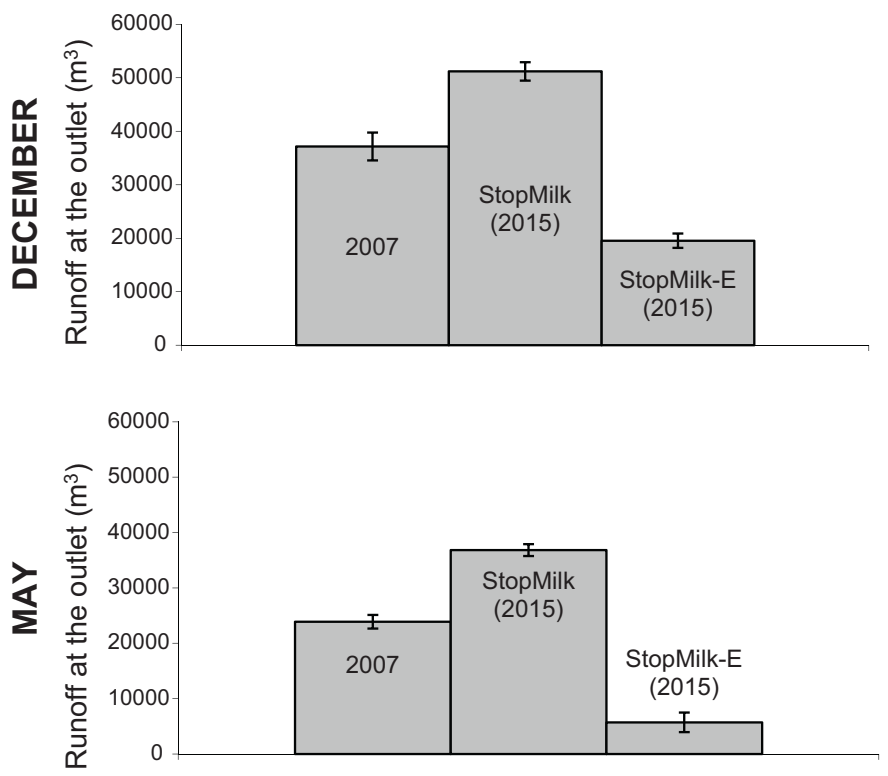

Fig. 3. Runoff volume $\left(\mathrm{m}^{3}\right)$ at the watershed outlet for $22 \mathrm{~mm}$ rainfall events in spring (May) and in winter (December) for the initial state (2007) and for the StopMilk and StopMilk-E scenarios. Mean values and standard error bars have been calculated for the 50 crop allocations generated by the LandsFacts model (see section "Presentation of the scenarios for 2015 and their environmental assessment").

(cf. Table 4), which leads to bare soils in winter but covered soils in spring.

\section{Economic evaluation of the StopMilk-E scenario}

We tested the decision tree (Fig. 2) on the 23 farms of the Saussay catchment. Table 4 shows that it correctly classifies 19 of the 23 farms. The decision tree gives good results for dairy farms which are targeted in particular by the 2015 scenario. Results are not as good for suckler farms. Applied to the entire Austreberthe watershed and using the RPG data, the decision tree allowed us to classify a total of 383 farms which had at least one crop islet within the Austreberthe watershed, consisting of 226 dairy farms (59\%), 112 suckler farms (29\%) and 45 cereal farms (12\%). The proportion of cereal farms was much greater in the Saussay catchment than in the Austreberthe watershed (21.5\%). The percentage of dairy farms and suckler farms in Saussay was 57\% and 21.5\%, respectively.

Additional costs were calculated by multiplying the crop areas in the 2015 scenario by the unit cost of practices available for the year 2007. These unit costs are given in Table 2, with the origin of the data mentioned below the table. Some of them, such as grass strips or catch crop costs, were set according to national regulations because they fell under French environmental policy. For the other costs we relied on references of varied extension services.

Table 4

Farm types in 2007 for the Saussay catchment: comparison between the real situation and that obtained with the decision tree (CF: cereal farm; DF: dairy farm; SF: suckler farm). Number and percentage (rounded values).

\begin{tabular}{cllllr}
\hline & & \multicolumn{2}{l}{$\begin{array}{l}\text { Classification according to } \\
\text { the decision tree }\end{array}$} & Total \\
\cline { 3 - 5 } & & CF & DF & SF & \\
\hline \multirow{2}{*}{ Real situation } & CF & $\mathbf{4 ( 1 7 \% )}$ & $1(4 \%)$ & $0(0 \%)$ & 5 \\
& DF & $0(\%)$ & $\mathbf{1 2 ( 5 2 \% )}$ & $1(4 \%)$ & 13 \\
& SF & $1(4 \%)$ & $1(4 \%)$ & $\mathbf{3 ( 1 3 \% )}$ & 5 \\
& Total & 5 & 14 & 4 & 23 \\
\hline
\end{tabular}

Bold values correspond to situations where the classification is correct (classification $=$ real situation)
Costs vary widely from one practice to another. Catch crops are expensive but have proven their effectiveness for a large part of the winter period and can be grown before any spring crop. Other practices have much lower costs (potato micro-dam) but can be used for a single crop, potatoes, whose surface areas are limited in the study zone. Finally, the in-field grass buffer strips, by definition, cover only a fraction of the surface areas of the fields concerned (estimated at $8 \%=20 \mathrm{~m}$ of strip for a length of $250 \mathrm{~m}$ ).

The additional cost of practices is given in Table 5 for both Saussay and Austreberthe as a whole. For Saussay, where results are available for both methods (LandsFacts and RPG), the cost structures of the two methods are comparable (\%). Rotary hoeing generates the highest costs, followed by catch crops. Other practices have much lower costs. The use of the RPG method leads to an over-estimation of costs by $34 \%$ when compared to the reference method using the LandsFacts model. The per-ha cost of UFA is $€ 36$ for LandsFacts and $€ 45$ for RPG.

If we compare Saussay to the Austreberthe watershed as a whole, the shares of costs are substantially the same. However, more specifically, the cost of practices in winter crop areas tends to increase (rotary hoeing, Table 2), whereas in areas with practices depending on spring crops the costs tend to decrease (mustard, micro-dam, grass buffer strip).The total cost for Austreberthe (RPG method) is just under $€ 640,000$, which comes to $€ 39 /$ ha of agricultural surface area. This cost is lower than that obtained for Saussay (€45/ha) with the same RPG method.

\section{Analysis of the global model's sensitivity}

Our model of cost estimation for Austreberthe is based on five main parameters of cropping system changes. Table 6 summarizes the definition of each of these parameters and the values used for the result presented in Table 5. The first three (P1, P2 and P3) concern the initial farm type, in 2007 (Fig. 2). The other two (P4 and P5) relate to the farms' evolution from 2007 to 2015. Table 6 also gives the minimum and maximum values that each parameter could take (values set by an expert) and the resulting percentage of variation of the total cost. In Table 6 we have also tested the effect of the cost value associated to each practice.

The sensitivity analysis on parameters linked to changes in cropping systems shows that the model's results are most sensitive to the values of parameter P4 (e.g. share of mandatory permanent grass which will not be converted into cropland when dairy farms disappear in the 2015 scenario). This share was initially set at $25 \%$, as an adaptation of the Saussay site value (18\%) to conditions in the entire Austreberthe watershed, characterized by a lower proportion of good soil (see section "Presentation of the scenarios for 2015 and their environmental assessment" and Table 1). A decrease in P4 values results in an increase in the area of the grasslands released when dairy farms are converted. When P4 decreases, dairy farms are more likely to be converted into cereal farms (growing spring barley as a cash crop) rather than into suckler farms (growing winter barley as a fodder crop). Spring barley implies the use of catch crops whose cost (per ha) is higher than that of rotary hoeing used for winter barley (Table 2). The sensitivity analysis on elementary costs of practices also shows a major effect of rotary hoeing (winter crops) on total costs. Variations in cost for the other practices have a very limited effect.

Using the range of variation of each parameter we can show that the total cost initially shown as $€ 640,000$ could be between $€ 540,000$ and $€ 773,000$ per year for the Austreberthe watershed.

\section{Determining willingness to pay (WTP)}

The results established for Commerce Valley (Table 7) show that individuals who are homeowners (variable Pro), in a high SPC (the 
Table 5

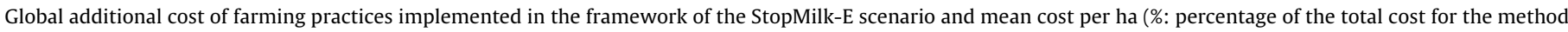
(either LandsFacts or RPG) applied to the study site).

\begin{tabular}{|c|c|c|c|c|c|c|}
\hline & \multicolumn{4}{|c|}{ Saussay 2015 (2720 ha) } & \multirow{2}{*}{\multicolumn{2}{|c|}{$\begin{array}{l}\text { Austreberthe } 2015 \text { (16,500 ha) } \\
\text { RPG (€39/ha) }\end{array}$}} \\
\hline & \multicolumn{2}{|c|}{ LandsFacts (€36/ha) } & \multicolumn{2}{|c|}{ RPG (€45/ha) } & & \\
\hline & $\%$ & $€$ & $\%$ & $€$ & $\%$ & $€$ \\
\hline Catch crop & 35.12 & 34,777 & 28.45 & 35,407 & 24.36 & 155,473 \\
\hline Potato micro-dam & 1.62 & 1605 & 2.16 & 2687 & 0.77 & 4892 \\
\hline Rotary hoeing & 55.75 & 55,194 & 61.19 & 76,148 & 69.58 & 444,222 \\
\hline Hoeing & 0.98 & 973 & 0.28 & 345 & 0.56 & 3585 \\
\hline In-field grass buffer strip & 6.53 & 6461 & 7.92 & 9860 & 4.73 & 30,172 \\
\hline Total & 100.00 & 99,010 & 100.00 & 124,447 & 100.00 & 638,344 \\
\hline
\end{tabular}

Table 6

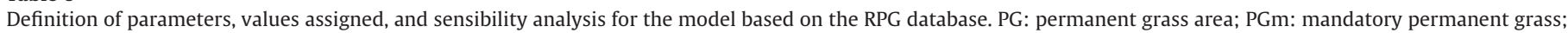
UFA: usable farm area; FM: forage maize area; FC: total forage crop area; FA: flax area; TAA: total arable area.

\begin{tabular}{|c|c|c|c|c|c|}
\hline & \multirow[t]{2}{*}{$\begin{array}{l}\text { Value used for } \\
\text { results in Table } 5\end{array}$} & \multirow[t]{2}{*}{ Definition } & \multicolumn{2}{|c|}{$\begin{array}{l}\text { Tested range of variation } \\
\text { for each parameter }\end{array}$} & \multirow[t]{2}{*}{$\begin{array}{l}\% \text { variation (Max- } \\
\text { Cost - MinCost)/MinCost }\end{array}$} \\
\hline & & & Min & Max & \\
\hline \multirow[t]{3}{*}{ Initial farm type in 2007 (Fig. 2) } & $\mathrm{P} 1=0.3$ & $\begin{array}{l}\text { Threshold of PG/UFA to distinguish between } \\
\text { cereal farms and suckler farms. If PG/UFA > P1 } \\
\text { then it is a suckler farm }\end{array}$ & 0.05 & 0.4 & $0 \%$ \\
\hline & $\mathrm{P} 2=0.15$ & $\begin{array}{l}\text { Threshold of FM/FC to distinguish between } \\
\text { dairy farms and suckler farms. If FM/FC > P2 } \\
\text { then it is a dairy farm }\end{array}$ & 0.1 & 0.45 & $5 \%$ \\
\hline & P3 = 15 ha & $\begin{array}{l}\text { Threshold of PG (ha) to distinguish between } \\
\text { cereal farms and suckler farms. If PG }>\text { P3 then } \\
\text { it is a suckler farm }\end{array}$ & 2 & 16 & $0 \%$ \\
\hline \multirow{2}{*}{$\begin{array}{l}\text { Changes in cropping plans } \\
\text { between } 2007 \text { and } 2015 \\
\text { (section "Presentation of the } \\
\text { scenarios for } 2015 \text { and their } \\
\text { environmental assessment") }\end{array}$} & $\mathrm{P} 4=0.25$ & $\begin{array}{l}\text { Mean value of PGm/PG. Defines the portion of } \\
\text { PG which will not be converted into cropland } \\
\text { when dairy farms disappear in the } 2015 \\
\text { scenario }\end{array}$ & 0.05 & 0.4 & $19 \%$ \\
\hline & $\mathrm{P} 5=0.05$ & $\begin{array}{l}\text { Threshold of FA/TAA for abandoning flax } \\
\text { farming in the } 2015 \text { scenario. If FA/TAA }<\text { P5 } \\
\text { then the farmer has given up flax cultivation }\end{array}$ & 0.01 & 0.15 & $1 \%$ \\
\hline \multirow[t]{5}{*}{ Practice cost (Table 2) } & $€ 75 /$ ha & Catch crop & 50 & 75 & $5 \%$ \\
\hline & $€ 10 /$ ha & Potato micro dam & 10 & 80 & $5 \%$ \\
\hline & $€ 43 /$ ha & Rotary hoeing (winter crop) & 39 & 46 & $12 \%$ \\
\hline & $€ 35 /$ ha & Hoeing (spring crop) & 25 & 60 & $0 \%$ \\
\hline & $€ 280 / \mathrm{ha}$ & Grass buffer strip (spring crop) & 250 & 320 & $1 \%$ \\
\hline
\end{tabular}

Table 7

Tobit model applied to the Commerce Valley for local inhabitants' willingness to pay.

\begin{tabular}{lrrrr}
\hline Variables & \multicolumn{1}{c}{ Coef. } & Std. Err. & \multicolumn{1}{l}{$T$} & $P>|t|$ \\
\hline Pro & 18.51 & 10.62 & 1.74 & 0.083 \\
Hab40 & -19.86 & 10.18 & -1.95 & 0.053 \\
Gift & -35.99 & 11.29 & -3.19 & 0.002 \\
Edu & 25.35 & 12.26 & 2.07 & 0.040 \\
Aware & -9.96 & 5.21 & -1.91 & 0.058 \\
OthSites & -87.50 & 19.57 & -4.47 & 0.000 \\
spcC & -32.88 & 16.44 & -2.00 & 0.047 \\
Agree & 100.58 & 29.18 & 3.45 & 0.001 \\
Log likelihood $=-456.98373$ & & & \\
$R^{2}=0.0791$ & & & & \\
\hline
\end{tabular}

Conditions on each variable for value = 1 : Pro: is homeowner; Hab40: has been living there for more than 40 years; Gift: donates to charities; Edu: has a high level of education; Aware: is aware of flooding processes; OthSites: has preference for the protection of another site; spcC: belongs to the lowest SPC (C); Agree: agrees with the overall program structure.

C SPC is the lowest) or with a high level of education (Edu) show more WTP than others. Interviewees who have good knowledge of the territory (Hab40) show less WTP than others. Finally, the wish to donate to other causes (gift), which reflects the individual's altruistic tendencies, or to pay for protection of other sites (OthSites), has a negative effect on the WTP.
The mean WTP stated by the individuals surveyed for this preservation program is $€ 22.63$ per year for 15 years. The aggregate WTP value for the entire program is to the order of $€ 570,000$ per year. Over 15 years, this corresponds to a total of 8.55 million Euros (undiscounted) from individuals for the mudflow-control program for Commerce Valley. For the Austreberthe watershed, if we assume the same mean WTP of $€ 22.63$ per year, the amount would be around $€ 395,000$ annually and 5.925 million Euros over 15 years. "The annual amount of $€ 395,000$ corresponds to 51\% of our highest estimate of the cost of changing farming practices as envisaged in the StopMilk-E scenario ( $€ 773,000)$. Considering the European subsidies of $50 \%$ (see section "Presentation of the scenarios for 2015 and their environmental assessment"), the local WTP would be able to balance out the global cost of the program."

\section{Discussion}

\section{The cost of agricultural practices}

Our starting point was to consider the extra cost for farmers (section "Presentation of the scenarios for 2015 and their environmental assessment"). Note that this calculation method excludes benefits that farmers may derive from some practices. For instance, for catch crops, nitrogen uptakes in soil can be used by the following crop and reduce the cost of fertilization for farmers. Depending 
on both the type of catch crop and the price of nitrogen, we can estimate that the benefit for farmers ranges from $€ 3$ to $€ 25 /$ ha. In Table 6 we have integrated this aspect in the lowest value given to the catch crop $(50=75-25)$ with no real consequences on the variation of the global cost (5\%). Farmers' benefits should also be considered for "potato micro dam", a technique originally developed to optimize the use of rain water by potato cover in semi-arid conditions (Agassi et al., 1989). Yet since the climate in SeineMaritime is oceanic, potato micro dam has no real benefits for farmers. Hoeing and rotary hoeing can also help farmers to reduce the cost of weeding. As the cost of chemical weeding is double that of mechanical weeding, there seems to be no need to subsidize it. But the cost of weeding is not the only criterion; if it were, all farmers would have adopted mechanical weeding. With chemical weeding they can intervene very quickly on all their fields, whereas mechanical weeding takes much longer. The number of available days to implement this technique is moreover limited in Normandy, as farmers must wait longer after each rainfall for the soil to dry. For these reasons, mechanical weeding can be of very poor quality and is often followed by chemical weeding in nonorganic farming (98.6\% of all farms in Seine-Maritime). The last type of practice, "grass buffer strips", can benefit farmers in agroecological systems but as most farming systems in Seine-Maritime are not agro-ecologically oriented, the benefits are negligible. To sum up, we can say that the cost of both hoeing and rotary hoeing is surely the most controversial one as theoretically the induced costs are balanced by the reduced weeding cost compared to chemical weeding (if calculated at the field level). Yet real benefits are far less obvious at the farm level, due to local conditions (farming system, soil and climatic conditions).

\section{The scale issue}

At the Austreberthe level (1) we did not carry out a runoff assessment because it was not possible (see section "Presentation of the scenarios for 2015 and their environmental assessment"). Instead, we relied on the assessment done at the Saussay level (2). We used the farm typology built for Saussay to determine the way cropping plans would change by 2015. The Saussay site is clearly representative of the upper part of the Austreberthe catchment (deep loamy soils), whereas the lower part of the Austreberthe area is characterized by steeper slopes and more clayey soils (see section "The study zone"). Due to these differences, two questions arise: (1) are we sure that for the lower part of the Austreberthe catchment the runoff assessment would have yielded the same results? (2) Can the types of farm in this lower part be slightly different of those encountered in the upper part?

On clayed soils, runoff will be limited and, due to steeper slopes and less easy-to-till soils, the share of mandatory permanent grass is probably higher for the lower part of Austreberthe than for Saussay. This can result in a limited loss of permanent grass and an effective but limited impact on runoff in both the StopMilk and the StopMilk-E scenarios (same ranking as for Saussay). The most important point regarding farm types is the identification of dairy farms, as they are the most strongly impacted by the scenario. In our decision tree (Fig. 2), dairy farms are identified through a high proportion of forage maize, although some dairy farms could be based on grass and classified as suckler farms. Information from local extension services shows that forage maize is a good indicator for dairy farms as dairy farms based on grass are rare and located outside of the Austreberthe catchment.

We have shown in Table 5 that the mean cost per ha was higher for Saussay than for global Austreberthe. The latter also has less diversified spring crops (see \% for potato micro-dam and in field buffer strip). These differences are explained by the fact that the land in the Saussay catchment (plateau border) is more suitable for crop farming than in the case of Austreberthe as a whole (sloping lands), which is more specialized in livestock.

\section{Analysis of willingness to pay}

The coefficients attributed to the variables in Table 7 show that interviewees with sound knowledge of the territory (Hab40) have a lower WTP than others. This observation can be explained by the fact that, historically, the area has experienced regular flooding, and that as a result the people who have been living there for more than 40 years are accustomed to this type of phenomenon. Interviewees who were aware of the flood risks (Aware) at the time they purchased property or moved to the area also tended to reveal a lower WTP than others. These individuals incorporate flood risks into their purchase decisions and are thus prepared to suffer the consequences without having to pay more. Moreover, they have often taken specific measures in their homes to drastically reduce the impact of such phenomena. A high level of education (Edu) positively influences WTP, as shown by Amigues et al. (2002). Conversely, a lower social status (SpeC) negatively influences WTP. To simplify, we can say that people who are less prone to pay are of a lower social status, with a low level of education. They have also lived in places with flood risks for a very long time, as these areas are less expensive.

\section{Comparison between cost of practices and willingness to pay}

The cost of farming practices (between $€ 540,000$ and $€ 773,000 /$ year) appears to be much higher than what the local populations are willing to pay ( $€ 395,000 /$ year). Owing to European subsidies, it may however be possible to compensate for the cost of farming practices. We must stress the fact that the calculated WTP is for the whole program presented in Appendix A and not only for farming practices. The specific WTP for farming practices remains unknown but is probably lower than the cost of farming practices, even if we have shown in Table 5 that the RPG method tended to overestimate the cost by $25 \%$ compared to the reference value (LandsFacts). To isolate the specific WTP for farming practices we should have used a choice experiment as proposed by Smyth et al. (2009). We have assumed that the practices would be implemented in all areas where such changes were possible. The environmental effectiveness of such a choice is shown in Fig. 3, even though it corresponds to a high cost for the community. Different solutions can be proposed to overcome this situation. An existing French law (Decree No. 2007-882, 05/14/2007) allows a community to stop funding such practices after the first 3 years, after which the farmers are required to continue them without any monetary compensation. The willingness to pay is calculated at a total of 5.925 million $€$ over 15 years. The funding required for the practices over three years would amount to $640,000 \times 3=1.920$ million Euros. On this basis, funding of the practices could become easier if the community borrowed money for the initial years of the program, and if the share of "farming practices" in the global WTP were sufficiently high. The loan can be repaid without any external aid after the first three years. This solution could also anticipate any reduction in the European subsidies.

To reduce the costs, it is also possible to concentrate on the most effective practices and optimize their implementation. For example, in-field grass buffer strips and a catch crop of mustard have proven to be more effective (Martin et al., 2010; Souchère et al., 2003) than other practices (rotary hoeing of cereals) and more sensitive to yearly climatic conditions (Ouvry et al., 2012). Locating these infiltration areas downstream of runoff fields can increase the environmental efficiency of the techniques without any change in cost (Joannon et al., 2006). A global reasoning could also be conducted to focus on the areas where change in agricultural 
practices would be the most effective and money saving (Jang et al., 2013) among the different watersheds of the Austreberthe catchment. This approach requires local advisers to help farmers to change their individual practices and to collectively manage small watersheds like Saussay more efficiently. The salary of these local advisers was included in the global program (Appendix A).

Relevance, limitations and future of the method

The method proposed and tested in this research seems to us to be a significant advance over existing ones, in several respects. It combines a multidisciplinary approach (agronomists and economists) at various organizational levels, ranging from the field to the farmland to the small hydrological catchment (Saussay) to the large hydrological watershed managed by a community. The method can be generalized over all of France because it is based on the French LPIS (RPG database), from which data is available for the entire country at a limited cost (a few hundred Euros per NUTS3 entity per year).

The proposed approach is nevertheless open to improvements. We linked the overall scenario to local descriptions with very simple rules (e.g. complete diappearance of some crops replaced by others maintaining the same proportion as in the original situation for each farm). This approach does not take account of economic factors like changes in crop prices for the remainning crops in the scenario context. To deal with these issues some micro-economic models - at the farm level - could have been used (Bamiere et al., 2011) but their use often requires a vast amount of data that are not always available. Farmers' demography is also another major factor that has not been taken into account.

The path to the scenario in relation to the facts

Since 2007 the environmental regulations on agricultural practices have changed in Seine-Maritime. First, the implementation of the new action program resulting from the nitrate directive led to the obligation to cover all cultivated soils in winter, as of December 2012. As this is mandatory, farmers cannot receive subsidies for it. During roughly the same period (2010), it was decided to prohibit permanent grassland plowing because too much grassland has been plowed up in France. In Seine-Maritime, data from the agricultural census show that the proportion of permanent grass in usable farm areas was 35\% in 2000 but decreased to $28 \%$ in 2010. At the same time, the economic crises that started in 2008 strongly limited the purchasing power of French citizens and turned their attention to issues other than flooding (e.g. unemployment). An updating of WTP in 2013 would probably show a lower level than that obtained in 2007. The question remains whether the reduction in WTP would correspond to the reduction of the global cost of the program due to the obligation to sow catch crops (24.36\% the global cost according to Table 5).

\section{Conclusion}

Results shown in Fig. 3 tend to indicate that from a technical point of view, a local public-action program (StopMilk-E) could compensate for undesirable changes in the overall agricultural socio-economic context (StopMilk) compared to the initial context of 2007. This result is interesting because StopMilk is one of the worst scenarios concieved of by experts for the horizon of 2015 .

The local public action program is based on an active policy of compensating farmers for regulation-mandated changes in farming practices. Such an approach is, however, expensive and requires a monitoring mechanism which is both technical (advice to farmers on maximizing the effects of the practices) and financial (e.g. borrowing in the first few years to be compensated for by the residents' payments in subsequent years).

The scenario built in 2007 is not likely to happen by 2015 . However, this scenario built with the Sysphamm methodology (Sebillotte and Sebillotte, 2010) has been an interesting tool for researchers and local experts to further understanding of the connections between different processes (supply chains evolution, changes in agricultural practices and environmental impacts) and to devise new solutions at every level of the decision chain.

\section{Acknowledgements}

We wish to thank Liz Libbrecht for language editing the article. This work was undertaken thanks to funding by the RDT program (Ministry of the Environment), INRA and the Haute-Normandie Region. 


\section{Appendix A.}

Q13- Do you agree with the idea that local inhabitants have to contribute to the

financial effort against flooding?

$\begin{array}{llll}\text { - YES } & & \text { - No } & 2=>\text { Q13B WHY?: } \\ & \end{array}$

Q14- Would you prefer to have this amount integrated into your local taxes or do you think it would be better to pay into a specific fund dedicated to flood control?

- local taxes $1 \quad$ - specific fund dedicated to flood control $2 \quad$ - I don't

know 3

"The program is split into 6 actions dedicated to runoff reduction. We are going to present each of them to you.

\begin{tabular}{|l|l|l|}
\hline \multicolumn{2}{|l|}{ Actions } & Description \\
\hline 1 & Set up of curative & Construction of storm-water basins (rain water retention \\
\hline
\end{tabular}

\begin{tabular}{|c|c|c|}
\hline & measures & in case of heavy rains) \\
\hline 2 & $\begin{array}{l}\text { Development of preventive } \\
\text { measures }\end{array}$ & $\begin{array}{l}\text { Agro environmental measures, pond structures, small } \\
\text { dykes, hedges }\end{array}$ \\
\hline 3 & $\begin{array}{l}\text { Monitoring of river level } \\
\text { with alerts in case of } \\
\text { flooding }\end{array}$ & $\begin{array}{l}\text { Electronic devices to monitor river level and } \\
\text { communication systems to warn local populations }\end{array}$ \\
\hline 4 & $\begin{array}{l}\text { Development of new } \\
\text { agricultural practices }\end{array}$ & $\begin{array}{l}\text { Information and training sessions for farmers to improve } \\
\text { their practices and limit runoff }\end{array}$ \\
\hline 5 & $\begin{array}{l}\text { Enhancement of rain water } \\
\text { use }\end{array}$ & $\begin{array}{l}\text { Information given to farmers, market gardeners and } \\
\text { inhabitants about rain water use }\end{array}$ \\
\hline 6 & $\begin{array}{l}\text { Recruitment of a } \\
\text { professional facilitator at } \\
\text { the watershed level }\end{array}$ & $\begin{array}{l}\text { The facilitator will directly organize information } \\
\text { operations for farmers and will supervise the other } \\
\text { actions of the program }\end{array}$ \\
\hline
\end{tabular}

Q15- Suppose that this program could halve both the magnitude and the frequency of flooding events. What would be the maximum amount that you would agree to pay each year for this program over a 15-year period (you keep paying your home insurance over this period)? This amount would be integrated into ... (preference given in Question 14) 
Q29 Did you change your opinion about your willingness to pay for the runoff

reduction program in the Commerce watershed after the last questions you had to

answer?

$\begin{array}{llll}- \text { Yes } & 1 & - \text { No } & 2\end{array}$

Q30- What would be the maximum amount that you would agree to pay each year for

this program over a 15-year period? (This program will halve the effects of flooding

events.)

/_ _ _ Euros/year over a 15-year period

Q31- How would you allocate the amount to the different actions of the program? [...]

\section{Appendix B. Supplementary data}

Supplementary data associated with this article can be found, in the online version, at http://dx.doi.org/10.1016/j.landusepol. 2013.12.014. These data include Google maps of the most important are as described in this article.

\section{References}

Agassi, M., Shainberg, I., Warrington, D., Ben-Hur, M., 1989. Runoff and erosion control in potato fields. Soil Science 148 (2), 149-154.

Amigues, J.P., Boulatoff, C., Desaigues, B., Gauthier, C., Keith, J.E., 2002. The benefits and costs of riparian analysis habitat preservation: a willingness to accept/willingness to pay contingent valuation approach. Ecological Economics 43, 17-31.

Arrow, K., Solow, R., Portney, P.R., Leamer, E.E., Radner, R., Schuman, H., January 1993. Report of the NOAA Panel on Contingent Valuation, Technical Report, no. 58., pp. 1601-1614.

Bamiere, L., Havlik, P., Jacquet, F., Lherm, M., Millet, G., Bretagnolle, V., 2011. Farming system modelling for agri-environmental policy design: the case of a spatially non-aggregated allocation of conservation measures. Ecological Economics 70 (5), 891-899.

Boardman, J., Ligneau, L., De Roo, A., Vandaele, K., 1994. Flooding of property by runoff from agricultural land in northwestern Europe. Geomorphology 10, $183-196$.

Boardman, J., Evans, R., Ford, J., 2003a. Muddy floods on the South Downs, southern England: problem and responses. Environmental Science and Policy 6, 69-83.

Boardman, J., Poesen, J., Evans, R., 2003b. Socio-economic factors in soil erosion and conservation. Environmental Science and Policy 6, 1-6.

Boardman, J., Verstraeten, G., Bielders, C., 2006. Muddy floods. In: Poesen, J., Boardman, J. (Eds.), Soil Erosion in Europe. Wiley, Chichester, pp. $743-758$.

Brouwer, R., Aftab, S., Brander, L., Haque, E., 2009. Economic valuation of flood risk exposure and flood control in a severely flood prone developing country. Environment and Development Economics 14, 397-417.

Castellazzi, M.S., Matthews, J., Angevin, F., Sausse, C., Wood, G.A., Burgess, P.J., Brown, I., Conrad, K.F., Perry, J.N., 2010. Simulation scenarios of spatio-temporal arrangement of crops at the landscape scale. Environmental Modelling \& Software 25, 1881-1889.

Cerdan, O., Souchère, V., Lecomte, V., Couturier, A., Le Bissonais, Y., 2002. Incorporating soil surface crusting processes in an expert-based runoff model: STREAM (Sealing and Transfer by Runoff and Erosion related to Agricultural Management). Catena 46, 189-205.

Evrard, O., Bielders, C.L., Vandaele, K., van Wesemael, B., 2007. Spatial and temporal variation of muddy floods in central Belgium, off-site impacts and potential control measures. Catena 70 (3), 443-454.

Evrard, O., Nord, G., Cerdan, O., Souchère, V., Le Bissonnais, Y., Bonté, P., 2010. Modelling the impact of land use change and rainfall seasonality on sediment export from an agricultural catchment of the northwestern European loess belt. Agriculture, Ecosystems \& Environment 138 (1/2), 83-94.

Ewert, F., van Ittersum, M., Bezlepkina, I., Therond, O., Andersen, E., Belhouchette, H., Bockstaller, C., Brouwer, F., Heckelei, T., Janssen, S., Knapen, R., Kuiper, M., Louhichi, K., Alkan Olsson, J., Turpin, N., Wery, J., Wien, J.E., Wolf, J., 2009. A methodology for integrated assessment of policy impacts in agriculture. Environmental Science and Policy 12 (5), 546-561.
Fullen, M.A., Arnalds, A., Bazzoffi, P., Booth, C.A., Castillo, V., Kerstesz, A., Martin, P., Ritsema, C., Sole Benet, A., Souchère, V., Vandekerckhove, L., Verstraeten, G., 2006. Government and agency response to soil erosion risk in Europe. In: Boardman, J., Poesen, J. (Eds.), Soil Erosion in Europe. John Wiley \& Sons, UK, pp. $805-828$.

Fuzeau, V., Dubois, G., Thérond, O., Allaire, G., 2012. Diversification des cultures dansl'agriculture française - état des lieux et dispositifs d'accompagnement. Commissariat général au développement durable. Etudes \& Documents, no. 67. $24 \mathrm{pp}$.

Godet, M., 2000. The art of scenarios and strategic planning: tools and pitfalls. Technological Forecasting and Social Change 65, 3-22.

Hanemann, W.M., 1994. Valuing the environment through contingent evaluation. Journal of Economic Perspectives 8 (4), 19-43.

Heitz, C., Spaeter, S., Auzet, A.V., Glatron, S., 2009. Local stakeholders' perception of muddy flood risk and implications for management approaches: a case study in Alsace (France). Land Use Policy 26 (2), 443-451.

Inan, H.I., Sagris, V., Devos, W., Milenov, P., van Oosterom, P., Zevenbergen, J., 2010. Data model for the collaboration between land administration systems and agricultural land parcel identification systems. Journal of Environmental Management 91, 2440-2454.

Jacquet, F., Butault, J.P., Guichard, L., 2011. An economic analysis of the possibility of reducing pesticides in French field crops. Ecological Economics 70, 1638-1648.

Jang, T., Vellidis, G., Hyman, J.B., Brooks, E., Kurkalova, L.A., Boll, J., Jaepil, C., 2013. Model for prioritizing best management practice implementation: sediment load reduction. Environmental Management 51, 209-224.

Joannon, A., Souchère, V., Martin, P., Papy, F., 2006. Reducing runoff by managing crop location at the catchment level, considering agronomic constraints at farm level. Land Degradation and Development 17 (5), 467-478.

Leenhardt, D., Angevin, F., Biarnès, A., Colbach, N., Mignolet, C., 2010. Describing and locating cropping systems on a regional scale. A review. Agronomy for Sustainable Development 30, 131-138.

Leteinturier, B., Herman, J.L., de Longueville, F., Quintin, L., Oger, R., 2006. Adaptation of a crop sequence indicator based on a land parcel management system. Agriculture, Ecosystems \& Environment 112, 324-334.

Martin, P., Joannon, A., Piskiewicz, N., 2010. Temporal variability of soil-surface runoff risk due to cropping systems in cultivated catchment areas: use of the DIAR model for the assessment of environmental public policies in the Pays de Caux (France). Journal of Environmental Management 91 (4), 869-878.

Mitchell, R., Carson, R., 1989. Using Surveys to Value Public Goods: The Contingent Valuation Method. Resources for the Future, Washington, DC.

Ouvry, J.-F., Coufourier, N., Richet, J.-B., Lhériteau, M., Pivain, Y., Martin, P., Lecomte, V., Barrier, C., Witkowski, D., Saint-Omer, L., Corruble, C., Luce, M., 2012. Maîtrise du ruissellement et de l'érosion des sols en Haute-Normandie. Expérimentations sur les pratiques culturales 2001-2010. Synthèse des résultats de ruissellement et d'érosion. Groupe Maîtrise du ruissellement par les pratiques culturales, $36 \mathrm{pp}$. http://www.rdtrisques.org/projets/digetcob/bib/ techniques_ruis/groupe_ruiss/syntheses/

Quiggin, J., 1998a. Individual, household and community willingness to pay for public goods. American Journal of Agricultural Economics 80 (1), 58-63.

Quiggin, J., 1998b. Existence value and the contingent valuation method. Australian Economic Papers 37 (3), 312-329.

Reidsma, P., Oude Lansink, A., Ewert, F., 2009. Economic impacts of climatic variability and subsidies on European agriculture and observed adaptation strategies. Mitigation and Adaptation Strategies for Global Change 14, 35-59.

Ronfort, C., Souchère, V., Martin, P., Sebillotte, C., Castellazzi, M.S., Barbottin, A., Meynard, J.M., Laignel, B., 2011. Methodology for land use change scenario assessment for runoff impacts: a case study in a north-western European Loess belt region (Pays de Caux, France). Catena 86, 36-48. 
Rounsevell, M.D.A., Annetts, J.E., Audsley, E., Mayr, T., Reginster, I., 2003. Modelling the spatial distribution of agricultural land use at the regional scale. Agriculture, Ecosystems \& Environment 95, 465-479.

Schönhart, M., Schmida, E., Schneider, U.A., 2010. CropRota - a crop rotation model to support integrated land use assessments. European Journal of Agronomy 34, 263-277.

Sebillotte, M., Sebillotte, C., 2010. Foresight in mission-oriented research: the SYSPAHMM foresight method (SYStem, Processes, Clusters of Hypotheses, Microand Macroscenarios). Futures 42, 15-25.

Smyth, R.L., Watzin, M.C., Manning, R.E., 2009. Investigating public preferences for managing Lake Champlain using a choice experiment. Journal of Environmental Management 90, 615-623

Souchère, V., King, C., Dubreuil, N., Lecomte-Morel, V., Le Bissonnais, Y., Chalat, M., 2003. Grassland and crop trends: role of the European Union Common Agriculture Policy and consequences for runoff and soil erosion. Environmental Science \& Policy 6, 7-16.
Therond, O., Belhouchette, H., Janssen, S., Louhichi, K., Ewert, F., Bergez, J.E., Wery J., Heckele, T., 2009. Methodology to translate policy assessment problems into scenarios: the example of the SEAMLESS integrated framework. Environmenta Science \& Policy 12, 619-630.

Valbuena, D., Verburg, P.H., Bregt, A.K., Ligtenberg, A., 2010. An agent-based approach to model land-use change at a regional scale. Landscape Ecology 25 185-199.

Verstraeten, G., Poesen, J., 1999. The nature of small-scale flooding, muddy floods and retention pond sedimentation in central Belgium. Geomorphology 29 (3/4), 275-292.

Zhai, G., Ikeda, S., 2006. Flood risk acceptability and economic value of evacuation. Risk Analysis 26 (3), 683-694.

Zhai, G., 2006. Public preference and willingness to pay for flood risk reduction. In: Ikeda, S., Fukuzono, T., Sato, T. (Eds.), A Better Integrated Management of Disaster Risks: Toward Resilient Society to Emerging Disaster Risks in Mega-cities. TERRAPUB and NIED, pp. 57-87, http://www.terrapub.co.jp/e-library/nied/ 